\title{
Past, present and future conservation of the greater one-horned rhinoceros Rhinoceros unicornis in Nepal
}

\author{
Kanchan Thapa, Santosh Nepal, Gokarna Thapa, Shiv Raj Bhatta \\ and ERIC WIKRAMANAYAKE
}

\begin{abstract}
Until the early 1980 s the only surviving population of the greater one-horned rhinoceros Rhinoceros unicornis in Nepal was in Chitwan National Park. Between 1986 and 200387 rhinoceroses from Chitwan were translocated into Bardia National Park and Suklaphanta Wildlife Reserve in the western terai region to establish founder populations and reduce the threat of local extinction from natural catastrophic events, disease and/or poaching. The founder populations increased in number through births but a rise in poaching during the period of civil strife in Nepal during 1996-2006 resulted in a dramatic decline in the populations, including in Chitwan. In 2001 the Terai Arc Landscape programme was initiated to connect 11 protected areas in Nepal and north-west India and facilitate dispersal of megafauna and manage them as metapopulations. Corridors that were restored under the programme and that connect Bardia and Suklaphanta with protected areas in India are now used by the greater one-horned rhinoceros. The successes and failures of the last 2 decades indicate that new paradigms for protecting rhinoceroses within and outside protected areas are needed, especially with reference to managing this species at a landscape scale.
\end{abstract}

Keywords Bardia, greater one-horned rhinoceros, metapopulation, Nepal, Rhinoceros unicornis, Suklaphanta, Terai Arc Landscape, translocation

\section{Introduction}

The historical range of the greater one-horned rhino1 ceros Rhinoceros unicornis extended along the floodplains of the Ganges, Brahmaputra and Sindh rivers from Pakistan to the Indo-Burma border (Amin et al., 2006). The species is now restricted, however, to nine populations, in

Kanchan Thapa (Corresponding author) Virginia Polytechnic Institute and State University, Blacksburg, Virginia 24061, USA.

E-mail kanchan1@vt.edu

Santosh NePAL, Gokarna Thapa and Shiv Raj Bhatta WWF Nepal, Baluwatar, Kathmandu, Nepal

Eric Wikramanayake Conservation Science Program, WWF US, Washington, DC, USA

Received 2 June 2011. Revision requested 6 July 2011.

Accepted 11 November 2011. protected areas in India and Nepal (Fig. 1; Menon, 1966). With the exception of the populations in Chitwan in Nepal, and Kaziranga National Park and Jaldapara Wildlife Sanctuary in India, the populations each number $<150$ individuals.

In the 19th century this rhinoceros was protected by the Rana rulers but individuals could be shot with a permit from the Maharajah or the Prime Minister. Later, during 19051939 many rhinoceroses were hunted by the British Royal Family (Rookmaker, 2004). But, nevertheless, until 1950 the Chitwan valley in Nepal held an estimated 1,000 rhinoceroses (Dinerstein, 2003). The valley was protected as a private hunting reserve for the Rana rulers, and the presence of malaria ensured that the alluvial grasslands and forests along the Himalayan foothill region, known as the terai, were sparsely populated by humans (Dinerstein, 2003). Only the indigenous Tharu tribal people, who have a greater immunity to malaria (Terrenato et al., 1988), were able to survive in the lowlands. But a successful malaria eradication programme in the late 1950s opened the terai and Chitwan valley to an influx of people, including flood victims from adjacent mountain districts and refugees fleeing the conflicts in Burma and Assam. The government also settled ex-servicemen and people from the mountains in the terai, through a planned resettlement scheme. Thus, large swathes of land were cleared for agriculture and settlements, resulting in extensive habitat loss and fragmentation (Dinerstein, 2003). As a consequence wildlife populations became isolated within habitat fragments and killing of wild animals trapped in these fragments was widespread by the mid 1950 s.

\section{Conservation in the early years (1950-1985)}

Under the Rana regime hunting the greater one-horned rhinoceros and tiger was exclusively reserved for royalty, and killing of these animals by other people was a criminal offence (Rookmaker, 2004). However, after the institution of democracy in 1950 and with the subsequent opening of the Rapti valley for settlement in Chitwan, large numbers of greater one-horned rhinoceroses were killed because selling the horn was lucrative. Gee (1959) reported that 72 rhinoceroses were poached in 1954 and 60 in 1958. Alarmed by the killing the government established a unit called the 


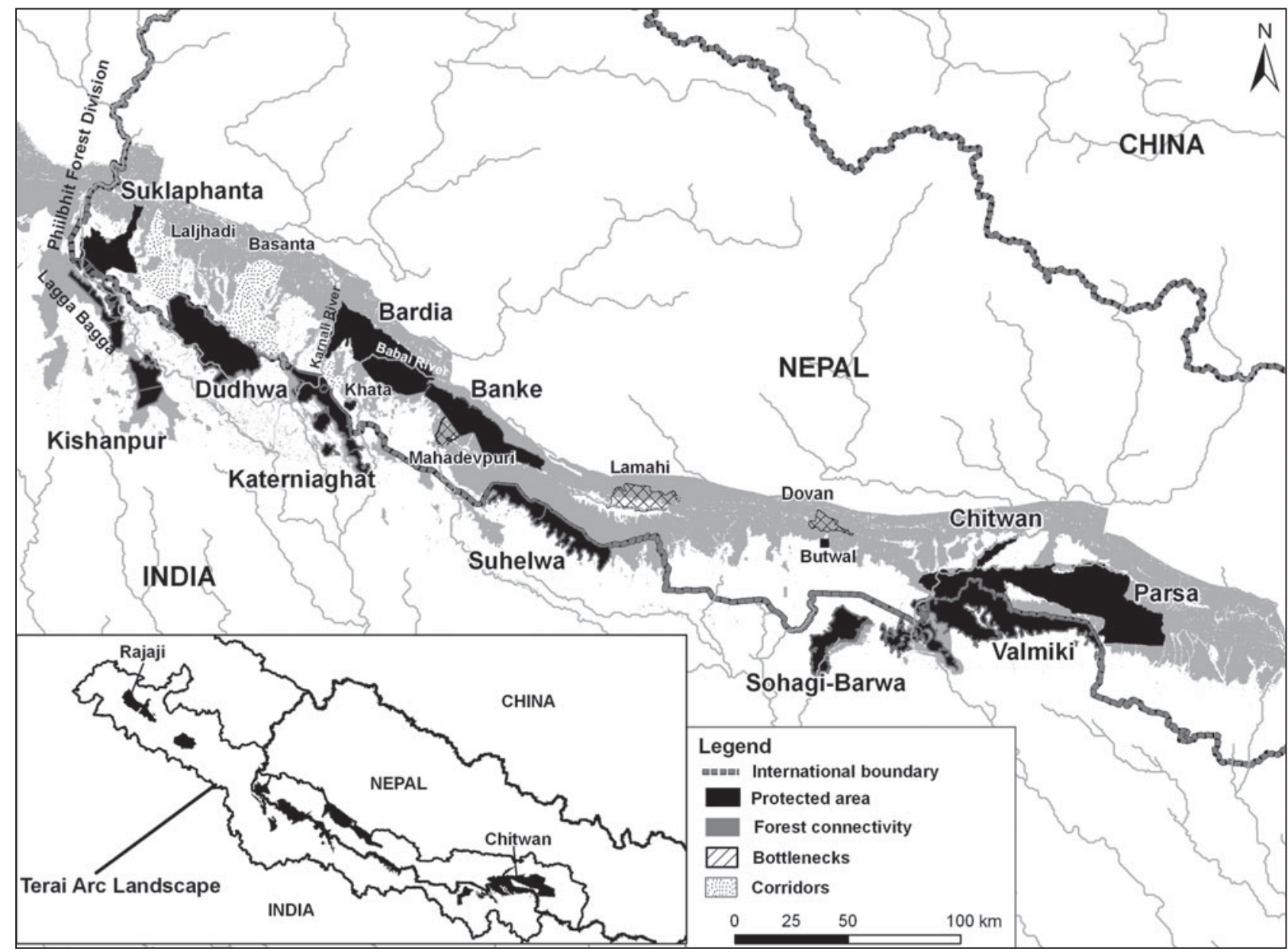

FIG. 1 The protected areas and corridors of the Terai Arc Landscape. The western terai complex consists of Bardia National Park, Suklaphanta Wildlife Reserve, Katerniaghat Wildlife Sanctuary, Dudhwa National Park, Kishanpur Wildlife Sanctuary and Lagga Bagga Forest Reserve.

Gainda Gasti (Rhino Patrol) in 1959, comprising 130 armed men whose role was to protect the rhinoceros in the Rapti Valley. The Wildlife Management Division Office at Tikauli oversaw the management of the Gainda Gasti. The Rana hunting reserve, which had been declared in 1934, was made a sanctuary (Mahendra Mirga Kunga) in 1954, and the Wildlife Conservation Act of 1958 was instituted, under which the greater one-horned rhinoceros was listed as a nationally protected animal.

However, poaching of the greater one-horned rhinoceros continued, and the problem became so severe that by the late 1960 s the rhinoceros population in the Chitwan Valley had dwindled to < 100 (Adhikari et al., 1999). In 1967 WWF initiated preliminary work in Nepal and helped to support and advocate conservation of the species. In 1971 the National Parks and Wildlife Conservation section was created within the Department of Forest Office, and in 1973 Chitwan National Park was declared Nepal's first national park, with the rhinoceros as the park's official logo. In 1975 the responsibility of protection in Chitwan was handed over to the Nepal Army and the Gainda Gasti was relegated to protection outside the core protected area. In 1993 the Gainda Gasti was absorbed into the existing cadre of armed forest guards within the Department of Forests. The National Parks and Wildlife Conservation office became the Department of National Parks and Wildlife Conservation in 1980. In 1982 the King Mahendra Trust for Nature Conservation was established as the pioneer national NGO to support conservation, including that of the greater one-horned rhinoceros (in 2008 the trust was renamed the National Trust for Nature Conservation).

\section{Translocations to establish founder populations (1985-2003)}

With the intensified protection system involving the army, and institutional strengthening of the Department of National Parks and Wildlife Conservation, the greater one-horned rhinoceros population in Chitwan National 
(a)

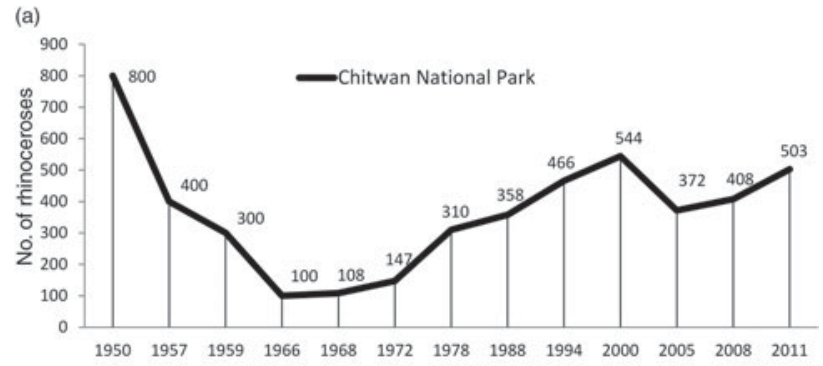

(b)

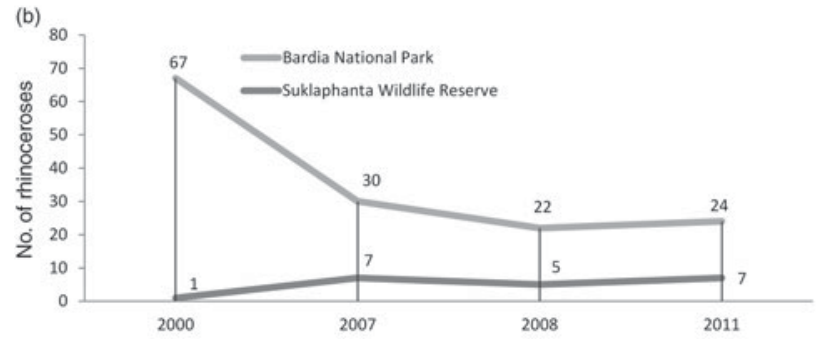

(c)

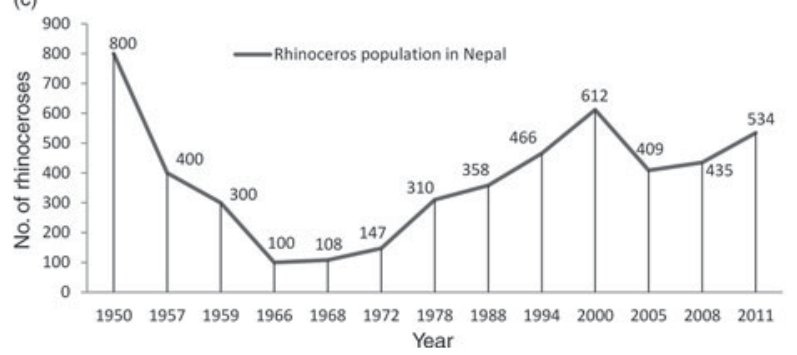

FIg. 2 Trend of the greater one-horned rhinoceros Rhinoceros unicornis population in (a) Chitwan National Park from 1950 to 2011, (b) Bardia National Park and Suklaphanta Wildlife Reserve from 2000 to 2011, and (c) overall population in Nepal.

Park increased steadily and in 2000 was estimated to be 544 (Fig. 2; DNPWC, 2000). In 1986 the Department of National Parks and Wildlife Conservation decided to establish founder populations elsewhere by translocating animals from the recovering Chitwan population. This project, initiated by the Government, resulted in two founder populations being established, in Bardia National Park and Suklaphanta Wildlife Reserve. This was a significant achievement of the first Rhinoceros Action Plan for Nepal (MoFSC, 2006). Eight translocations took place between 1986 and 2003, during which a total of 87 rhinoceros were translocated at an average cost of USD 4,000 each (A. Manandhar, WWF, pers. comm.). During the capture process domesticated elephants were used to search and flush rhinoceroses to be darted for translocations. Captures were usually undertaken during the dry season (MarchMay), when visibility is high.

In 198613 rhinoceroses (eight males, five females) were translocated from Chitwan to the Karnali River floodplain along the westernmost boundary of Bardia National Park. Based on a population and habitat viability analysis, the Asian Rhino Specialist Group recommended that the founder populations be increased to $>100$ (Molur et al.,
1995). Therefore, between 1991 and 200370 additional rhinoceroses (30 males, 40 females) were translocated to the Babai River floodplain, in the heart of Bardia (Table 1).

In 2000 a second founder population was established, in Suklaphanta Wildlife Reserve, which formerly held a single male rhinoceros. Although the recommendation was for 10 rhinoceroses to be translocated (Yonzon et al., 2003) only four (one male, three female) were released, in the core area of the reserve (Fig. 2). The population in this Reserve is now estimated to be seven (Table 2; DNPWC, 2011). Three deaths have occurred from natural causes (WWF, 2006).

\section{Poaching and population declines}

Between 1986 and 200027 calves were born in Bardia National Park, almost $50 \%$ of the number translocated (58 animals) into the Park during this period. A count in 2000 estimated the population to be 67 (DNPWC, 2000), which accounted for $\mathrm{c} .18$ rhinoceroses that had been lost to natural deaths and poaching (Dinerstein, 2003). However, a survey in 2007 failed to find any animals in the Babai River floodplain, whereas 31 animals were counted in the Karnali River floodplain. The increase in the number of rhinoceroses in the latter area could have partly resulted from animals moving there from the Babai River valley. In 2008 22 rhinoceroses were counted across the Karnali floodplain plain and again no rhinoceroses were recorded in the Babai River floodplain. In 2008 a small population was also recorded in Katerniaghat Wildlife Sanctuary in India, downstream of Karnali River, indicating that some rhinoceroses from Bardia had dispersed across the border (Menon, 1996; DNPWC, 2008). A count in 2011 found 24 individuals in the Karnali River floodplain (Table 2).

The primary cause of the decline in the Bardia rhinoceros population, including the local extirpation in Babai, was thought to be poaching. As the Babai valley had a history of poaching, four strategic posts were constructed in the valley before the rhinoceroses were translocated there. These were manned by groups of $10-15$ soldiers who were to patrol the area to deter and prevent poaching. This proved successful initially but between 2003 and 2006 Nepal's long-standing civil conflict intensified and Babai valley became an area of conflict. The small army posts were consolidated into a single large post for security reasons and patrolling was suspended. Thus, most of the park, and Babai Valley in particular, remained unstaffed and unprotected, leaving rhinoceroses and other wildlife vulnerable to poaching. The rapidly growing demand for traditional oriental medicines that use rhinoceros and tiger parts (Martin et al., 1997) and the illegal trade in wildlife parts to support this demand (Wilde, 2010), made rhinoceroses more lucrative for poachers, who had relatively free access to the Babai Valley during this period of intensified civil conflict. While poaching accounted for the majority of rhinoceros deaths 
TABLE 1 Translocation chronologies of the greater one-horned rhinoceros Rhinoceros unicornis from Chitwan National Park.

\begin{tabular}{llcccl}
\hline Year & Month & Male & Female & Total & Translocated to \\
\hline 1986 & February & 3 & 1 & & Karnali river floodplain (Bardia National Park) \\
& December & 5 & 4 & 13 & \\
1991 & January & 6 & 14 & 20 & Babai river floodplain (Bardia National Park) \\
& February & 2 & 3 & 5 & Babai river floodplain (Bardia National Park) \\
1999 & January & 4 & 0 & 4 & Babai river floodplain (Bardia National Park) \\
2000 & March & 5 & 5 & 10 & Babai river floodplain (Bardia National Park) \\
& November & 3 & 3 & 6 & Babai river floodplain (Bardia National Park) \\
2001 & November & 1 & 3 & 4 & Suklaphanta Wildlife Reserve \\
2002 & March & 2 & 3 & 5 & Babai river floodplain (Bardia National Park) \\
2003 & March & 5 & 5 & 10 & Babai river floodplain (Bardia National Park) \\
Total & April & 3 & 7 & 10 & Babai river floodplain (Bardia National Park) \\
\hline
\end{tabular}

TABLE 2 Sex and population structure of the greater one-horned rhinoceros population in Nepal in 2011.

\begin{tabular}{|c|c|c|c|c|c|c|c|}
\hline \multirow[b]{2}{*}{ Location } & \multirow[b]{2}{*}{ Male } & \multirow[b]{2}{*}{ Female } & \multirow{2}{*}{$\begin{array}{l}\text { Sex } \\
\text { unidentified }\end{array}$} & \multirow[b]{2}{*}{ Total } & \multicolumn{3}{|c|}{ Age structure } \\
\hline & & & & & Adult & Subadult & Calf \\
\hline Chitwan National Park & 145 & 183 & 175 & 503 & 332 & 60 & 111 \\
\hline Karnali river floodplain (Bardia National Park) & 5 & 9 & 10 & 24 & 15 & 4 & 5 \\
\hline Babai river floodplain (Bardia National Park) & 0 & 0 & 0 & 0 & 0 & 0 & 0 \\
\hline Suklaphanta Wildlife Reserve & 2 & 2 & 3 & 7 & 4 & 2 & 1 \\
\hline Total & 152 & 194 & 188 & 534 & 351 & 66 & 117 \\
\hline
\end{tabular}

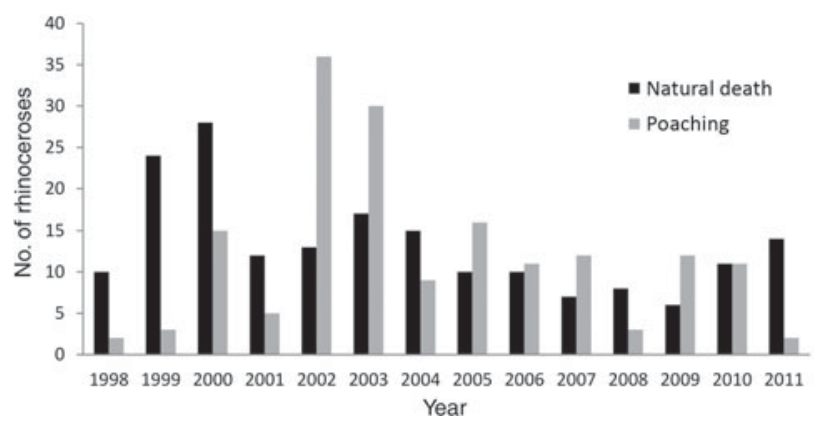

FIG. 3 Annual mortality, from natural deaths and poaching, of the greater one-horned rhinoceros in Nepal from 1998 to 2011.

between 2000 and 2011, several animals were also thought to have been lost to natural causes (Fig. 3), including predation and intraspecific conflict.

Alarmed by the situation the Department of National Parks and Wildlife Conservation, with WWF Nepal, launched a nationwide programme, Operation Unicornis, in 2007 (TAL, 2008). The aims were to seek political commitment for the consideration of wildlife crime as a serious issue and to increase commitment among local communities to conserve the animal that is emblematic to the country. As a part of this programme a community-based intelligence network was established. The Department of National Parks and Wildlife Conservation, with WWF Nepal, the National Trust for Nature Conservation, the Zoological Society of London and the UK Darwin Initiative, launched rhinoceros block monitoring and MIST
(Management Information System; ESS, 2009). MIST uses the law enforcement monitoring system designed by the Wildlife Conservation Society. This system is a patrol-based monitoring system that provides regular and rapid information on illegal activities and performance of protected area staff. Individual rhinoceroses were also identified, based on unique features, and monitored. There has been a $7.7 \%$ annual growth rate in the rhinoceros population in Nepal from 435 individuals in 2008 (DNPWC, 2008) to 534 individuals in 2011 (DNPWC, 2011).

\section{Restoring populations and corridors (2001-2010)}

The Terai Arc Landscape programme was initiated in 2001 to manage the megafauna that lives along the Himalayan foothills as metapopulations, by linking 11 protected areas in southern Nepal and north-western India with habitat corridors to facilitate dispersal (Wikramanayake et al., 2004). Metapopulations are considered to have greater probability of long-term viability and persistence than small, isolated populations (McCullough, 1996). In this programme Bardia National Park and Suklaphanta Wildlife Reserve, with Dudhwa National Park, Katerniaghat Wildlife Sanctuary, Kishanpur Wildlife Sanctuary, and Lagga Bagga Forest Reserve (a part of Philiphit Forest Division) in India, form a cluster of core areas that could harbour a metapopulation of the greater one-horned rhinoceros (Fig. 1).

In this programme transboundary corridors were restored to link Bardia with Katerniaghat, and Suklaphanta 
with Dudhwa, Lagga Bagga and Kishanpur (Fig. 1; Wikramanayake et al., 2010). Greater one-horned rhinoceroses have begun to use the corridors: five rhinoceroses from Bardia travelled through the corridor to Katerniaghat and are now resident there.

Rhinoceroses from Suklaphanta have begun to venture into India's Lagga Bagga forest. (Fig. 1). In 2005 and 2006 Park officials in Suklaphanta recorded photographs of a female and calf that had not been translocated into the Reserve (WWF, 2006). These two rhinoceroses, along with a male that was found in Suklaphanta prior to the initial translocations, are believed to have come from Dudhwa National Park in India through the Laljhadi corridor. The presence of these rhinoceros in Suklaphanta and dispersal of rhinoceroses from Suklaphanta to Lagga Bagga indicate that these corridors contain functional habitat.

The corridors were restored through community forestry projects that elicited community stewardship for conservation, and the rhinoceros has been protected by communityled anti-poaching teams (Wikramanayake et al., 2010). Sightings of rhinoceroses in the Khata corridor, between Bardia and Katerniaghat, are now common, and they use several shallow waterholes, which have been constructed in the corridor, as wallows. The Khata corridor is emerging as a tourist location. In 2011 a home-stay programme for tourists was initiated, and in the first 3 months the communities earned USD 3,000 through ecotourism activities (TAL, 2011).

During the 5 years since community-led anti-poaching units were established to patrol, and to protect wildlife in the corridors, there has been no evidence of poaching of rhinoceroses in the Khata and Laljhadi corridors, despite heavy poaching in the protected areas. Between 2005 and 2008 the anti-poaching teams apprehended 19 poachers and dismantled or confiscated several traps and weapons (TAL, 2009).

\section{The future of the greater one-horned rhinoceros}

Protection is the key to the successful recovery of the greater one-horned rhinoceros in Nepal. With an annual population growth rate of $7.5 \%$, anti-poaching initiatives such as block monitoring, MIST (ESS, 2009) and ID-based monitoring, both in protected areas and in the corridors, need to be strengthened. Protection units need to have regular training to ensure the effective patrolling of the core and buffer zones, and to facilitate this protection a system of allweather patrol trails and roads needs to be developed.

As a result of the translocations initiated during 19862003 there are now three core greater one-horned rhinoceros populations (in Chitwan and Bardia National Parks and Suklaphanta Wildlife Reserve) in Nepal and an established population in India's Dudhwa National Park. There is also a nascent population in Katerniaghat Wildlife
Sanctuary. All are linked through corridors that are being used by rhinoceroses. There is also potential for rhinoceroses to disperse into Lagga Bagga forest and Kishanpur Wildlife Sanctuary, which would create a metapopulation consisting of six core populations in the western Terai Arc Landscape.

However, much remains to be accomplished to ensure a viable greater one-horned rhinoceros population, especially given potential emerging threats. As rhinoceroses begin using the corridors more frequently they will inevitably venture into bordering agriculture areas and settlements, resulting in conflict with humans. There needs to be an incentive structure associated with the conservation of the greater one-horned rhinoceros in this human-dominated landscape. Proactive conflict mitigation programmes are needed, along with installation of suitable barriers to prevent crop depredation, and promotion of behavioural adjustments amongst local people to minimize encounters. Lessons can be learned from West Bengal where rhinoceroses and people co-exist as a result of successful conservation, community awareness and development programmes (Martin, 2006). The ecotourism programmes in Khata and the buffer zone of Chitwan are examples of such an incentive.

The greater one-horned rhinoceros population in Chitwan National Park recovered from 60-80 animals in the early 1960 s to $>500$ animals in 2011 (Dinerstein, 2003; Amin et al., 2006; DNPWC, 2011). Despite recovering from a precipitous decline this population was found to have high genetic diversity (observed heterozygosity, $\mathrm{H}_{\mathrm{o}}=0.43 \pm \mathrm{SD}$ o.29) and to be a genetically distinct population (Zschokke et al., 2011). This could be explained by the large historical population, the high vagility of the species and the relatively quick recovery of the population (Dinerstein \& Mccracken, 1990). However, the founder populations in Bardia and Suklaphanta were established by translocating small numbers of rhinoceroses from the Chitwan population, selected from a small area, and these populations may not therefore represent the range of genetic variability in the Chitwan population. Therefore, we recommend occasional translocations of males from Chitwan to both of the other parks, to avoid inbreeding depression (Ralls et al., 1976; Zachos et al., 2007).

\section{Lessons learned}

There are now at least two metapopulations in the western part of the terai. One is based around Bardia and Katerniaghat, which serve as core areas, with rhinoceroses using the Khata corridor for transboundary movement. The other is around the cluster of protected areas consisting of Suklaphanta, Dudhwa, Lagga Bagga and Kishanpur. Thus, the vision of the Terai Arc Landscape programme, to maintain habitat corridors for dispersal and to manage the 
megafuna as metapopulations, seems to be becoming a reality (WWF, 2006; TAL, 2010; Wikramanayake et al., 2010). However, because of the commercial demand for rhinoceros horn Nepal has to maintain vigilance and protection to prevent any resurgence of poaching. Under the landscape conservation paradigm successful protection includes engagement of community stewards. The successes in the Terai Arc Landscape of engaging local communities are lessons for landscape-scale conservation of free-ranging megafauna in other such landscapes.

\section{Acknowledgements}

We are grateful to Dr Eric Dinerstein for his guidance in writing this paper, and to Dr Marcella J. Kelly, Pradeep Khanal and an anonymous reviewer for their useful comments. We thank Diwakar Chapagain (WWF Nepal) for his suggestions and comments and Dr Amrita Thapa for her help with editing.

\section{References}

Adhikari, T.R., Pradhan, N.M.B. \& Poudel, N. (1999) A Strategy to Combat Poaching in Chitwan Valley. Department of National Parks and Wildlife Conservation, Kathmandu, Nepal.

Amin, R., Thomas, K., Emslie, R.H., Foose, T.J. \& Van Strien, N. (2006) An overview of the conservation status of and threats to rhinoceros species in the wild. International Zoo Yearbook, 40, 96-117.

Anon (2001) Project Tiger Status Report. Ministry of Environment and Forests, Government of India, Delhi, India.

Dinerstein, E. (2003) The Return of the Unicornis: The Natural History and Conservation of the Greater One-Horned Rhinoceros. Columbia University Press, New York, USA.

Dinerstein, E. \& Mccracken, G.F. (1990) Endangered greater onehorned rhinoceros carrying high level of genetic variation. Conservation Biology, 4, 417-422.

DNPWC (Department of National Parks and Wildlife Conservation) (2000) Count Rhino 2000 Initial Report. Department of National Parks and Wildlife Conservation, Kathmandu, Nepal.

DNPWC (Department of National Parks and Wildlife Conservation) (2008) Status and Distribution of Greater Onehorned Rhinoceros in Nepal. DNPWC, Kathmandu, Nepal.

DNPWC (Department of National Parks and Wildife Conservation) (2011) Rhino Count 2011 Report. Department of National Parks and Wildlife Conservation, Kathmandu, Nepal.

ESS (Ecological Software Solutions) (2009) MIST v. 2.2.3.4. Hegymagas, Hungary.

Foose, T.J. \& VAn Strien, N. (1997) Asian Rhinos-Status Survey and Conservation Action Plan. IUCN, Cambridge, UK.

Gee, E.P. (1959) Report on a survey of the Rhinoceros area of Nepal. Oryx $, 5,59$.

Martin, E.B. (2006) Policies that work for rhino conservation in West Bengal. Pachyderm, 41, 74-84.

Martin, E.B., Vigne, L. \& Allan, C. (1997) On a Knife's Edge: The Rhinoceros Horn Trade in Yemen. The CITES 1997 Series. TRAFFIC International, Cambridge, UK.
McCullough, D.R. (1996) Metapopulations and Wildlife Conservation. Island Press, Washington, DC, USA.

Menon, V. (1996) Under Siege: Poaching and Protection of Greater One-horned Rhinoceroses in India. TRAFFIC International, Cambridge, UK.

MoFSC (Ministry of Forest and Soll Conservation) (2006) The Greater One-horned Rhinoceros Conservation Action Plan for Nepal (2006-2011). Ministry of Forest and Soil Conservation, Kathmandu, Nepal.

Molur, S., Sukumar, R., Seal, U. \& Walker, S. (1995) Report-Population and Habitat Viability Assessment (PHVA) Workshop for Greater Indian One-horned Rhinoceros. Conservation Breeding Specialist Group (CBSG)-India, Coimbature, India.

Ralls, K., BRUGGer, K. \& Ballou, J. (1976) Inbreeding and juvenile mortality in small populations of ungulates. Science, 206, $1101-1103$.

RoOKMAKer, K. (2004) Fragments on the history of the rhinoceros in Nepal. Pachyderm, 37, 73-79.

STOKES, E.J. (2010) Improving effectiveness of protection efforts in tiger source sites: developing a framework for law enforcement monitoring using MIST. Integrative Zoology, 5, $363-377$.

TAl (Terai Arc Landscape) (2008) Annual Report: Critical Bottleneck and Restoration Project. WWF Nepal \& Department of Forest, Kathmandu, Nepal.

TAl (Terai Arc Landscape) (2009) Annual Report: Critical Bottleneck and Restoration Project. WWF Nepal \& Department of Forest, Kathmandu, Nepal.

TAl (Terai Arc Landscape) (2010) Annual Report: Critical Bottleneck and Restoration Project. WWF Nepal \& Department of Forest, Kathmandu, Nepal.

TAl (Terai Arc Landscape) (2011) Annual Report: Terai Arc Landscape Protected Areas and Buffer Zone. WWF Nepal \& Department of National Parks and Wildlife Conservation, Kathmandu, Nepal.

Terrenato, L., Shrestha, S., Dixit, K.A., Luzzatto, L., Modiano, G., Morpurgo, G. \& Arese, P. (1988) Decreased malaria morbidity in the Tharu people compared to sympatric populations in Nepal. Annals of Tropical Medicine and Parasitology, $82,1-11$.

Wikramanayake, E.D., McKnight, M., Dinerstein, E., Joshi, A., Gurung, B. \& Smith, J.L.D. (2004) Designing a conservation landscape for tigers in human-dominated environments. Conservation Biology, 18, 839-844.

Wikramanayake, E.D., Manandhar, A., Bajimaya, S., Nepal, S., Thapa, G. \& Thapa, K. (2010) The Terai Arc Landscape: A tiger conservation success story in a human-dominated landscape. In Tigers of the World (eds R. Tilson \& P.J. Nyhus), pp. 163-173. Elsevier, San Diego, USA.

WILde, L.W. (2010) Wildlife crime: a global problem. Forensic Science Medicine Pathology, 6, 221-222.

WWF (2006) Annual Wildlife Monitoring Report, Terai Program (ed. K. Thapa). WWF Nepal, Kathmandu, Nepal.

Yonzon, P., Adhikari, T.R. \& Subedhi, N. (2003) Systematic Approaches in Rhino Translocation. WWF Nepal, Kathmandu, Nepal.

Zachos, F.E., Althoff, C., Steynitz, Y.V., Eckert, I. \& HartL, G.B. (2007) Genetic analysis of an isolated red deer (Cervus elaphus) population showing signs of inbreeding depression. European Journal of Wildife Research, 53, 61-67.

Zschokke, S., Armbruster, G.F.J., Ursenbacher, S. \& Baur, B. (2011) Genetic differences between the two remaining wild populations of the endangered Indian rhinoceros (Rhinoceros unicornis). Biological Conservation, 144, 2702-2709. 


\section{Biographical sketches}

KanCHAN THAPA has conducted several surveys of the rhinoceros and tiger in the Terai Arc and is a member of the Asian Rhino Specialist Group. Santosh NePAL is the director of Policy and Support at WWF Nepal. He was the expert member of the Natural Resource Economic Right and Revenue Sharing Committee of the
Constitutional Assembly (2009-2010). Gokarna Thapa is the geographical information system specialist at WWF Nepal. SHIV RA J BH A T A A worked as chief warden for more than a decade in Chitwan and Bardia National Parks before joining WWF Nepal as programme coordinator for the Terai Arc Landscape programme. ERIC WiKRAMANAYAKE works with landscape-level approaches to conservation. 